\title{
INFLUENCE OF ORTHOGONAL BURNISHING PARAMETERS ON SURFACE CHARACTERISTICS FOR VARIOUS MATERIALS
}

\author{
M. H. El-AXIR* and M. M. EL-KHABEERY** \\ *Assistant Professor, ${ }^{* *}$ Associate Professor, Department of Production \\ Engineering and Mechanical Design, Faculty of Engineering, Shebin \\ El-kom, Egypt. \\ E-mail: ealaxir@yahoo.com
}

\begin{abstract}
Burnishing is used increasingly as a finishing operation which gives additional advantages such as increased hardness, fatigue strength, wear resistance. It is well known that burnished surface characteristic can significantly affect the resistance of components to failure when subjected to high cycle fatigue loads. The fatigue crack, in general, nucleates at the surface of the part, and then propagates into the bulk. Consequently, it is the state of the surface characteristic, where the crack nucleates, that is of paramount importance.

Experimental work was carried out on a lathe to establish the effect of four roller burnishing tool parameters; namely, burnishing speed, burnishing depth, burnishing time and the initial hardness of material on the surface microhardness, the out-of-roundness and the reduction in workpiece diameter.

It was found that all input parameters have a controlling effect, with different percentage, on the three output responses. The results showed that burnishing depth and burnishing time are the most important parameters controlling the values of both out-of-roundness and reduction in workpiece diameter. Also, an increase in burnishing speed leads to a considerable reduction in the microhardness index. Out-of-roundness increases with a decrease in the initial hardness of workpiece material
\end{abstract}


During recent years, considerable attention is being paid to the postmachining metal finishing operations such as burnishing which improves the surface characteristics by plastic deformation of the surface layers $[1,2]$. Burnishing is essential a cold-forming process, in which the metal near a machined surface is displaced from protrusion to fill the depressions. Beside producing a good surface finish, the burnishing process has additional advantages over other machining processes, such as securing increased hardness, corrosion resistance and fatigue life as a result of the producing compressive residual stress. Residual stresses are probably the most important aspect in assessing integrity because of their direct influence on performance in service. Thus, control of the burnishing process (burnishing conditions) in such a way as to produce compressive residual stresses in the surface region could lead to a considerable improvement in component life.

A comprehensive classification of burnishing tools and their application has been given by Shneider [3]. A literature survey shows that work on the burnishing process has been conducted by many researchers and the process also improves the properties of the parts, for instance; increased hardness [4-8], surface quality $[2,4,9,10]$, increased maximum residual stress in compression [4,11], and higher wear resistance $[12,13]$ The parameters affecting the surface finish are: burnishing force, feed rate, ball material, number of passes, workpiece material, and lubrication [2].

This paper examines the use of a specially roller burnishing tool to give a good surface characteristic such as, surface microhardness, surface roundness and the reduction in workpiece diameter. The latter plays an important role on the required tolerance and fit especially during assembly parts. The effect of four parameters, namely; burnishing speed, burnishing time, burnishing depth and hardness of workpiece materials, on the three different output mentioned above was studied

\section{EXPERIMENTAL WORK}

In this study, 2014 Aluminum alloy, brass, and three different carbon steel materials; namely, A387 Grade II, A285, and A 455 Type I, (according to ASTM specification) were used as workpiece materials. These materials were selected because of their importance in industry and their susceptibility to degradation when burnished, through surface and subsurface damage. The chemical analysis, in weight percent, of these materials is shown in Table 1. Specimens were turned and burnished on a center lathe Model DIZ 450x 1600, WMW, Germany. 
Table 1: Chemical composition of workpiece materials in weight

percent

\begin{tabular}{|c|c|c|c|c|c|c|}
\hline \multirow{15}{*}{ 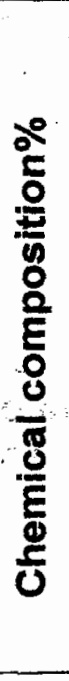 } & \multicolumn{6}{|c|}{ Material } \\
\hline & & $\begin{array}{c}\text { Aluminu } \\
\text { m } 2014\end{array}$ & Brass & A335-grade11 & A285-gradeC & $\begin{array}{l}\text { A455- } \\
\text { type1 }\end{array}$ \\
\hline & $\mathbf{F e}$ & 0.7 & 0.043 & & & \\
\hline & C & & & 0.17 & 0.28 & 0.33 \\
\hline & $\mathrm{Cu}$ & $3.9-5$ & 57.68 & & & \\
\hline & $M n$ & $0.4-1.2$ & & $0.4-0.65$ & 0.90 & $0.85-1.2$ \\
\hline & $\mathrm{Mg}$ & $0.2-0.8$ & & & $\infty$ & \\
\hline & $\mathrm{Cr}$ & 0.1 & & $1-1.5$ & $\Leftrightarrow$ & \\
\hline & $\mathbf{Z n}$ & 0.25 & 40.29 & & & \\
\hline & $\mathrm{Ti}$ & 0.15 & & & & \\
\hline & Mo & & & $0.45-0.65$ & & \\
\hline & $\mathbf{S}$ & & & 0.04 & 0.045 & 0.05 \\
\hline & $\mathbf{P}$ & & & 0.035 & 0.035 & 0.4 \\
\hline & $\mathbf{P b}$ & i & 1.99 & 3 & & \\
\hline & Si & $0.5-1.2$ & & $0.5-0.8$ & & 0.10 \\
\hline
\end{tabular}

The five different materials were received in the form of seamless tube that was machined into ring-shaped workpiece having dimensions shown in Fig.1. The workpieces were prepared with two parts A and B. Part (A) was left without burnishing for comparison. In the burnishing tests, the ring-shaped specimens were held by means of screw and nut in a specially made mandrel, the direction of the burnishing roller pressure being perpendicular to the axis of rotation of workpiece. Figure 2 shows a ring-shaped specimen attáched to the mandrel. The surface hardness of each specimen was measured along the length and around the periphery. A microhardness tester (SHIMSADZU MICRO HARDNESS TERSTER TYPE-M) was used in these measurements. Burnishing process usually reduces the workpiece dimensions in the direction of main deformation. The reduction in the diameter was measured at three different places for each test using a horizontal microscope (CARLZEISS MODEL 2063).

It is practically impossible to produce the geometry of engineering products perfectly in agreement with the ideal dimensions of the component. A roundness error is considered as one of the important geometrical errors for cylindrical components because it has negative effects on accuracy and other important factors such as the fitting of machine elements, and wear in rotating elements. The roundness is obtained as the difference between the maximum and minimum radii of the measured profile. Roundness variation was measured using a Circularity error device Model (RANDCOM IC AFFERENT).

The microhardness of both the pre-machined and burnished surfaces were measured using Vicker's hardness tester (SHIMSADZU MICRO HARDNESS TESTER TYPE-M). A pyramid diamond indentor with $136^{\circ}$ apex and indentation load of $1 \mathrm{kgf}$ was used. The average hardness of 
the pre-machined surface for the five materials used in this work were taken.

A specially designed burnishing tool is shown in Fig. 3 which consists of two steel parts. The first part is the base that can be held on the tool post of the lathe whereas the other part is made to hold the roller freely. A roller bearing having an outside diameter of $22 \mathrm{~mm}$ and a width of $6 \mathrm{~mm}$ was fitted to the tool.

The input factors under investigation in the experiments were; burnishing speed, burnishing depth, and burnishing time and initial hardness of the workpiece materials. The effect of theses parameters on the microhardness increase, reduction in diameter, and out-ofroundness was studied. Table 2 shows the value of the burnishing parameters used in the present work.

Table 2: Summary of burnishing parameters range

\begin{tabular}{|llc|}
\hline Burnishing speed, & $(\mathrm{m} / \mathrm{s})$ & $1.04-2.341$ \\
Burnishing depth, & $(\mathrm{mm})$ & $0.4-1.2$ \\
Burnishing time, & $(\mathrm{sec})$ & $10-50$ \\
Material hardness, & $(\mathrm{BH})$ & $50=90$ \\
Roller diameter & $(\mathrm{mm})$ & 22 \\
Burnishing condition & & Lubricated \\
\hline
\end{tabular}

\section{RESULTS AND DISCUSSION}

It is to be expected that the burnishing process causes a change in the surface microhardness, and a reduction in dimension related to surface roughness because the burnishing tool flats topographical peaks. Outof-roundness plays an important role on the efficiency of any round mechanical part that rotates during work. A shaft as an example, may appear to be round to the eyes. It may even have a constant diameter when measured with any instrument but when examining the shape on a greatly enlarged scale it could be seen as shown in Fig. 4. It is clear that the lobes will carry most of the load of the shaft when it runs in a plain bearing. This leads to a less efficiency than that the required by the designer.

Out-of-roundness of any mechanical part could be due to deflection of the workpiece as a result of the forces generated during cutting. Also, out-of-roundness may be produced as a result of tool wear or incorrect in position. The range of out-of-roundness error of any mechanical part depends strongly on cutting parameters, namely, cutting speed, feed rate, depth of cut and tool geometry that control the behavior of both tool forces and tool wear. One of the main objectives of this work is to study the effects of burnishing process on the out-of-roundness. Figure 5 shows, for example, a comparison between the out-of-roundness error before (turning) and after burnishing process for one test. 
It is interesting to report that the out-of-roundness considerably reduces as a result of burnishing at all parameters levels used in this work. Also, it is interesting to mention that about $2 \mu \mathrm{m}$. out-of-roundness error can be obtained by burnishing process. The result could be considered as a new advantage of burnishing process.

To study and discuss the effect of the input parameters on the three different responses, figures 6-11 are constructed showing the results of these three responses on the same figure.

\section{Burnishing Speed}

The effect of burnishing speed on the microhardness index, reduction in workpiece diameter (reduction in diameter) and the variation of outof-roundness can be assessed from Figs.6-8. The results reveal that an increase in burnishing speed leads, in general, to a reduction of the microhardness index. This is partly due to the fact that the deforming action of the roller is smaller at high speed and partly due to the chatter that usually induces at high speed.

It can generally be seen for the various burnishing depth, time, initial hardness used in this work that reduction in workpiece diameter decreases with an increase in burnishing speed, reaching a minimum value at a burnishing speed of $2.006 \mathrm{~m} / \mathrm{s}$. A further increase in speed causes an increase in reduction in workpiece diameter. It is believed that the increase in the diameter change at low speed is possible due to the high deforming action of the rollers of burnishing tool.

Also, from the same figures, it can be seen that as the burnishing speed increases (from 1.04 to $1.6993 \mathrm{~m} / \mathrm{s}$ ) the out-of-roundness first decreases to a minimum value. With a further increase in burnishing speed, out-of-roundness begins to increase gradually. A combination of high speeds with high value of any one of the other parameters used in this work increases the out-of-roundness because of chatters which usually occurs at this condition

\section{Burnishing Depth}

Burnishing depth is one of the very important burnishing parameters that affect the results of this four roller-burnishing tool. It can be seen form Fig. 6, that for a given speed, an increase in burnishing depth causes an increase in both microhardness index and reduction in diameter of the burnished surface. The increase in both microhardness index and the reduction in diameter when employing high burnishing depth can be attributed to the increase of the roller pressure on the workpiece surface resulting in compressing the most aspirities and increase the metal flow which leads to the filling of more voids that were exited in subsurface layer due to machining operation (turning, or as a metal defect). The out-of-roundness of the burnished surface, as shown in the above figures, decreases as the burnishing depth 
increasea as a result of the regularity of the metal flow on the burnished surface.

Figure 9 presents the relationship between the three output responses measured in this work and burnishing depth for different burnishing times. There are two interactions in this figure, the first is between both burnishing depth and burnishing time and the microhardness index. $A$ combination of low burnishing depth with high burnishing time leads to a substantial improvement in the microhardness-index. A combination of high burnishing depth with high burnishing time deteriorates the microhardness index. It is believed that this occurs because of the over hardening and consequently flaking of the surface layers.

The second interaction is between the same two parameters and the reduction in diameter. The magnitude of depth that gives low reduction in diameter depends on the value of time during burnishing process. Also, it can be realized that the combination between high roller depth and high burnishing time results in an increase in diameter reduction. This can attributed to repetition of burnishing process for the same work under the specified penetration

Also, the results of this figure show that at high burnishing depth, the increase in burnishing time results in an increase in the out-ofroundness. It is believed that combination of large burnishing depth with long burnishing time leads to over hardening and then flaking. The best results were obtained at the combination of low burnishing time with high burnishing depth as shown in Figure 9.

\section{Burnishing Time}

The effect of burnishing time on the three different responses studied is shown in Figs. 7, 9 and 11. The results of these Figs. show that the burnishing time is one of the most controlling parameters having influence on the change in the results of the three responses. These figures, generally reveal that as the burnishing time increases the microhardness index increases first till it reaches a maximum value. This is because of the repeated burnishing process on the same workpiece surface at high burnishing time leads to an increase in the structure homogeneity which results in an increase in the surface responses. With a further increase in burnishing time, the microhardness index increase begins to decrease gradually. This is because, increasing the burnishing time more than a certain time deteriorates the results because of the over hardening and consequently flaking of the surface layers as a result of more repeated roller burnishing tool on the same workpiece surface.

The highest variation in workpiece diameter can be obtained at high burnishing time. Magnitude of burnishing time that gives low reduction in diameter depends on the burnishing depth.

It is clear that for a given burnishing speed and/or initial hardness of the workpiece material, an increase in burnishing time leads to a decrease 
in the out-of-roundness. It is interesting to discuss the reasons why the out-of-roundness is decreased. It is thought that the repeated contacts between the tool (roller) and workpiece, the elastic contact is achieved for most the contact area and the plastic deformation occurs only at the minute area around the center of contact of the burnishing so that plastic deformation does not extend over the surroundings.

\section{Initial Hardness of Material}

The influence of the initial hardness of workpiece material on the microhardness index, the reduction in diameter dimension and the outof-roundness at different burnishing speed; burnishing depth on and burnishing time is shown in Figs. 8,10 , and 11. In general, at a given burnishing speed or burnishing time, the microhardness index of the burnished surface increases as the initial hardness increased from 50 to $70 \mathrm{HB}$. With a further increase in initial hardness, the microhardness index begins to decrease gradually.

Figure 10 shows that there is an interaction between both initial hardness of material and burnishing depth and the microhardness index. At low initial hardness of workpiece material, an increase in the burnishing depth leads to an increase in the microhardness index. However, at high initial hardness an increase in burnishing depth decreases the microhardness index.

It can be seen from these figures that the reduction in diameter first decreases with an increase in initial hardness to a minimum as a result of the increasing of the ability of the workpiece surface to resist the roller burnishing tool pressure. With a further increase in the initial hardness of workpiece material over $70 \mathrm{HB}$, the reduction in workpiece diameter increases as a result of over hardening.

The general trend of the results of out-of-roundness is that lowering the initial hardness of material leads to a considerable increase in the outof-roundness. This may occur as a result of the irregularity of the metal flow. Therefore, it is better to conduct burnishing process on medium or hard metal to obtain a significant decrease in the out-of-roundness.

\section{CONCLUSIONS}

1- The output responses of the burnished surface are mainly influenced by the four parameters used, namely; burnishing speed, burnishing depth, burnishing time and initial hardness of the workpiece materials. The burnishing depth and burnishing time play a major role and their effects can be considered as the most important input parameters

2- An increase in burnishing speed leads to a decrease in both the microhardness index and reduction in workpiece diameter whereas the increase in burnishing speed more than $1.5 \mathrm{~m} / \mathrm{sec}$ results in a considerable increase in out-of-roundness.

3- An increase in burnishing depth leads to a considerable increase in both surface microhardness and reduction in workpiece diameter 
whereas it causes a decrease in the out-of-roundness. Burnishing depth interacts with both burnishing time and initial hardness of workpiece material. The best results for surface microhardness obtained at both low burnishing depth with high burnishing time and/or high burnishing depth with low initial hardness of material.

4- The best results for out-of-roundness is obtained when applying high burnishing depth with low burnishing time.

5- The initial hardness of workpiece material is one of the most important parameters controlling the effects of the other parameters on each response. There are many interactions between initial hardness of material and other parameters used in this work.

6- The results can be interpreted in terms of over hardening, flaking, layer deformation, and structure of the work material.

\section{REFERENCES}

[1] Kukielka L.," Designating the Field Areas for the Contact of A Rotary Burnishing Element with the Rough Surface of A Part, Providing A High-Quality Product", Journal of Mechanical Technology, Vol. 19, pp. 319-356, 1989.

[2] Loh N. H., Tam S. C., and Miyazawa S.," A Study of the Effects of Ball-Burnishing Parameters on Surface Roughness Using Factorial Design", Journal of Mechanical Working Technology, Vol.18, pp. 53-61, 1989.

[3] Shneider Yu. G.,"Classification of Metal-Burnished Methods and Tools, Machines and Tooling", Vol. XL, No. 1, p. 35, 1969.

[4] Hassan A. M. and Al-Bsharat A. S.," Influence of Burnishing Process on Surface Roughness, Hardness, and Microstructure of Some Nom-Ferrous Metals", Wear, Vol. 199, pp. 1-8, 1996.

[5] El-Axir M. H.,"An Investigation Into Roller Burnishing", International Journal of Machine tool \& Manufacturing, Vol. 40, pp. 1603-1617, 2000.

[6] Loh N. H., Tam S. C., and Miyazawa S.," Statistical Analyses of the effects of ball Burnishing Parameters on Surface Hardness", Wear, Vol. 129, pp. 235, 1989.

[7] Yashcheritsyn I., Pyatosin E.I. and Votchuga V. V.,"Hereditary Influence of Pre-treatment on Roller-Burnishing Surface wear Resistance", Soviet Journal of Friction and Wear, Vol. 8, No.2, pp. 87,1987.

[8] Fattouh M.; El-Axir M. H., Serage S. M.,"Investigation into the Burnishing of External Cylindrical surface of $70 / 30 \mathrm{Cu}-\mathrm{Zn}$-Alloy", Wear, Vol. 127, No. 2, pp. 123-137, 1988.

[9] Lee S.S.G., Tam S.C., Loh N.H. and Miyazawa S.,"An Investigation into the Ball Burnishing of an AISI 1045 Free-Form Surface", Journal of Materials Processing Technology, Vol. 29, P. 203, 1992.

[10] Lee S.S.G., Tam S.C., and Loh N.H.," Ball Burnishing of 316L Stainless Steel, Journal of Materials Processing Technology, Vol. 37, P. 241, 1993.

[11] Fattouh M. and El-Khabeery M. M.,"Residual Stress Distribution in Burnishing Solution Treated and Aged 7075 Aluminum Alloy", Int. J. Mach. Tools \& Manufact., Vol. 29, No. 1, P. 153, 1989. 
[12] Niberg A. N.,"Wear Resistance of Sideways Strengthened by Burnishing", Soviet Engineering Research, Vol.7, No.5, P. 67, 1987.

[13] Michael P. C., Saka N. and Rabinowicz E.," Burnishing and Adhesive wear of an Electrically Conductive Polyester-Carbon Film", Wear, Vol. 132, P. 265, 1989. 

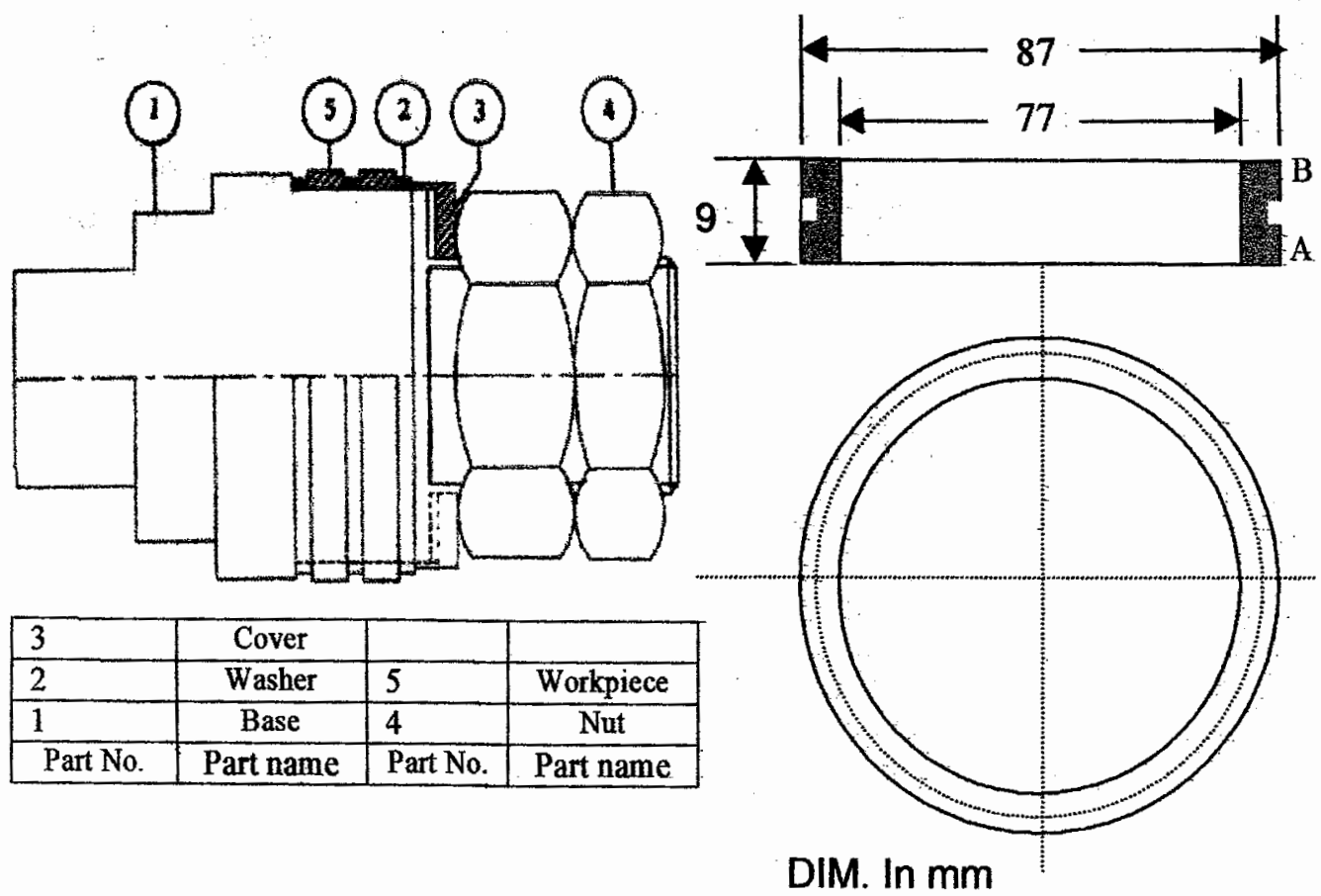

Figure 1: Workpiece geometry

Figure 2: Mandrel and workpiece assembly
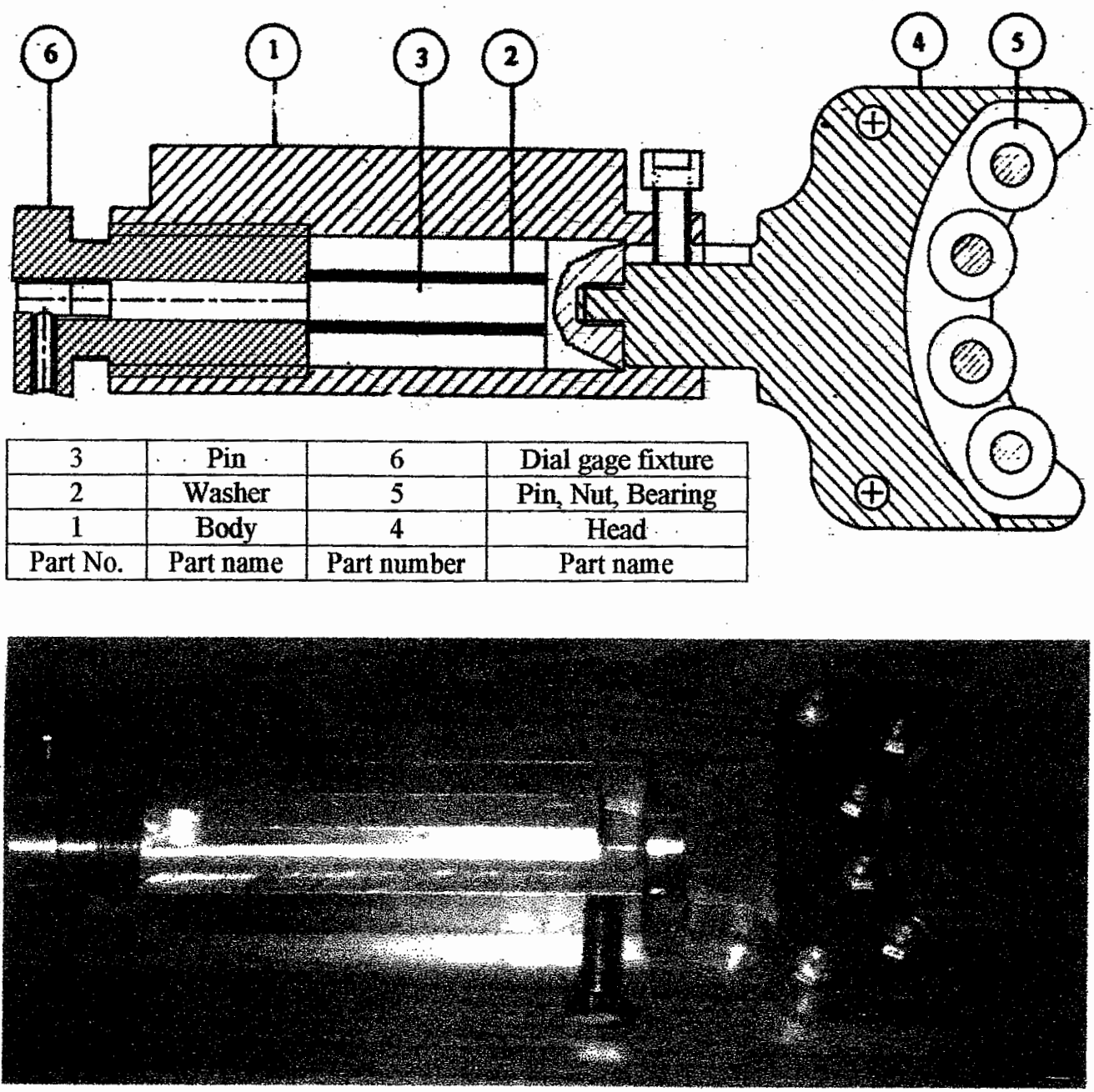

Figure 3: Four roller burnishing tool 


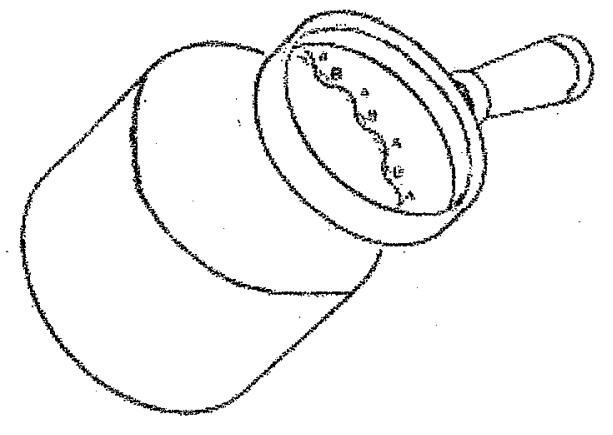

Fig. 4a Shaft diameter (enlarged view)

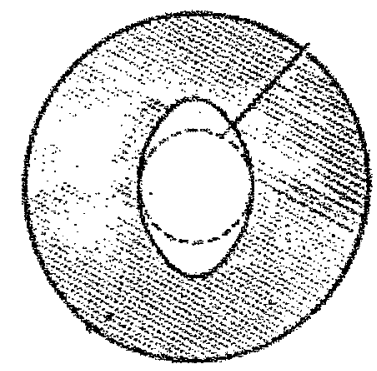

Fig. $4 b$ Shaft ovality

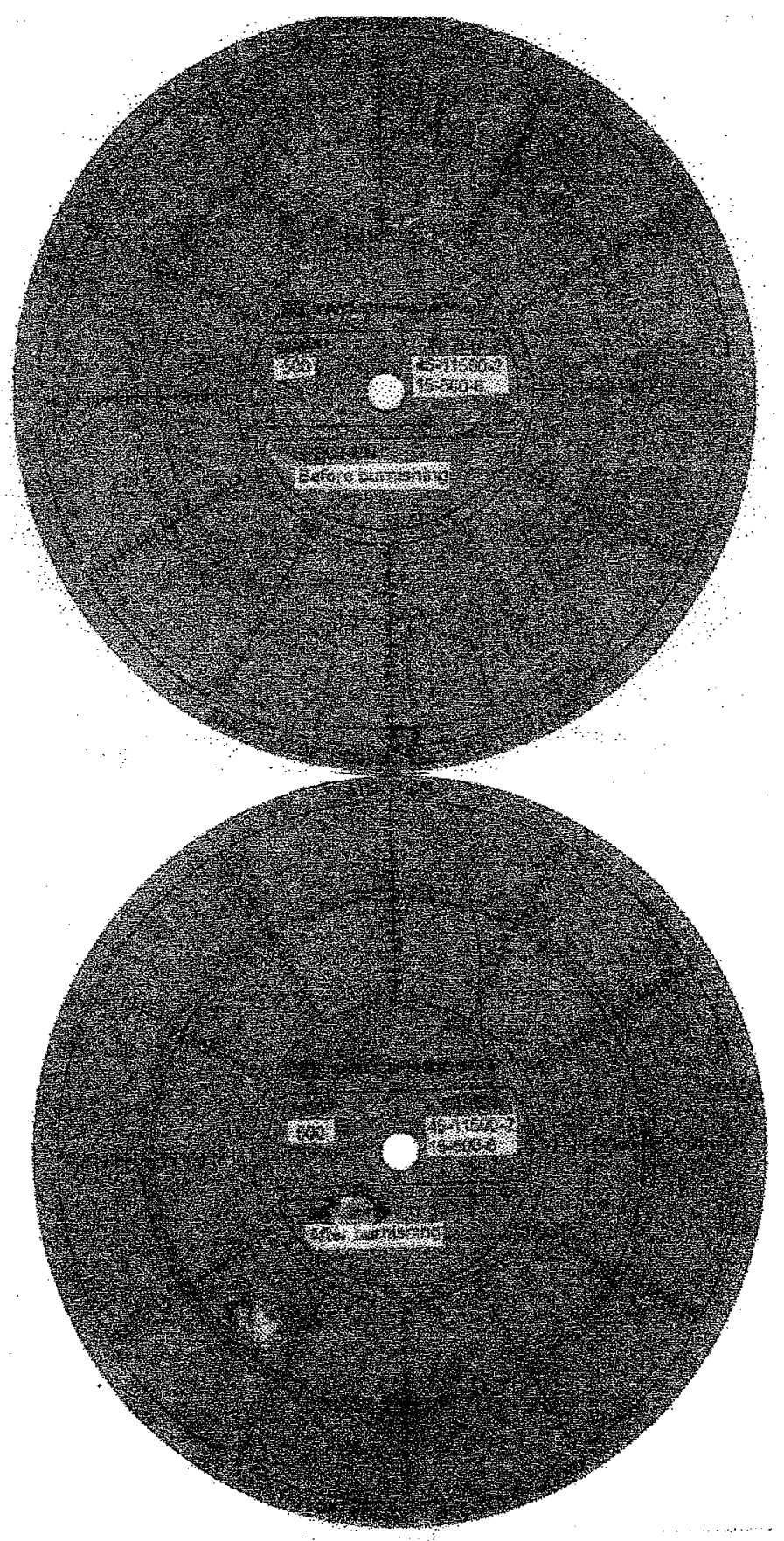

Fig. 5 Out-of-roundness before and after burnishing 


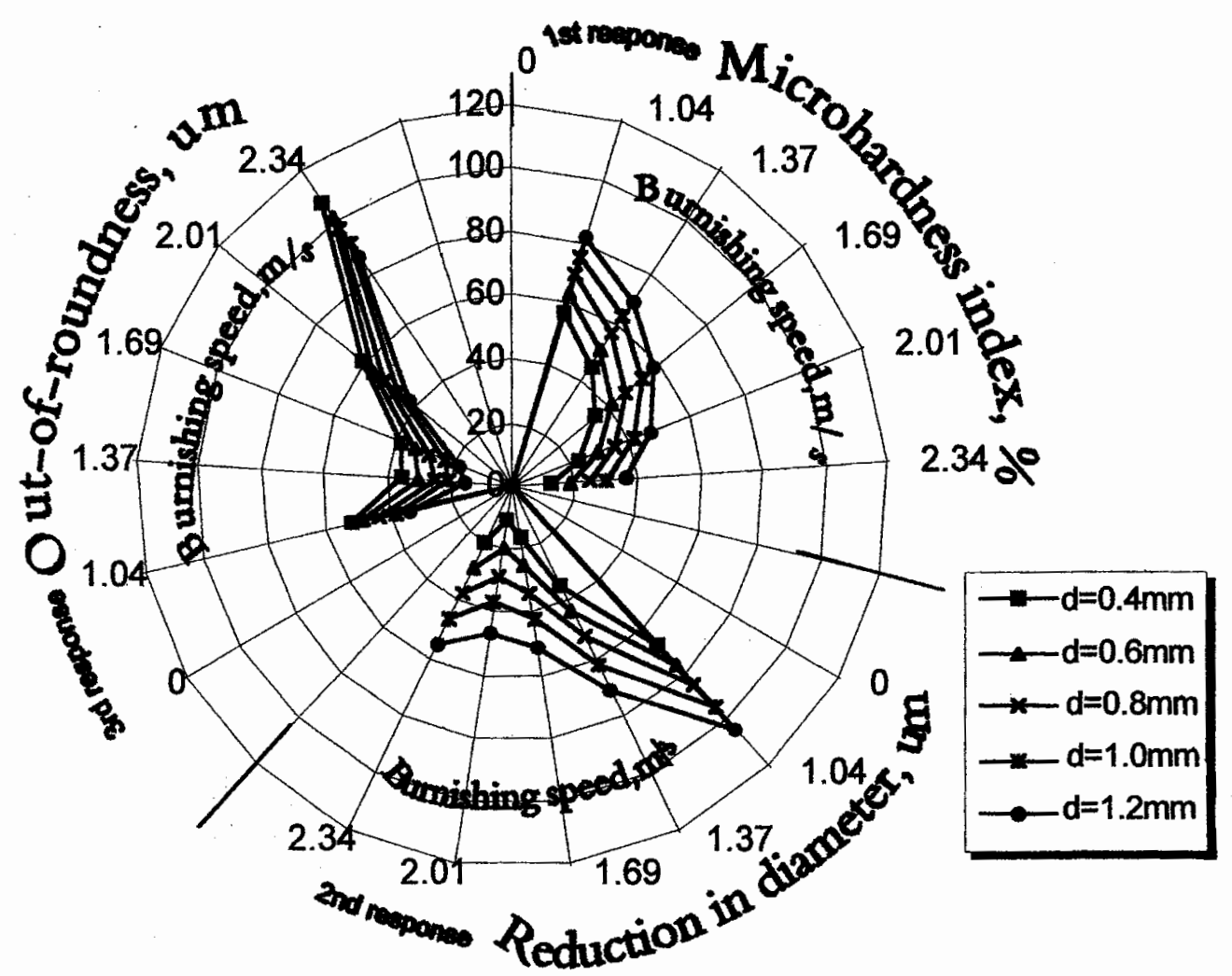

Figure 6: Effect of burnishing speed and burnishing depth on microhardness index, reduction in diameter and out-of-roundness at $t=30 \mathrm{sec}$ and $\mathrm{H}=70 \mathrm{HB}$.

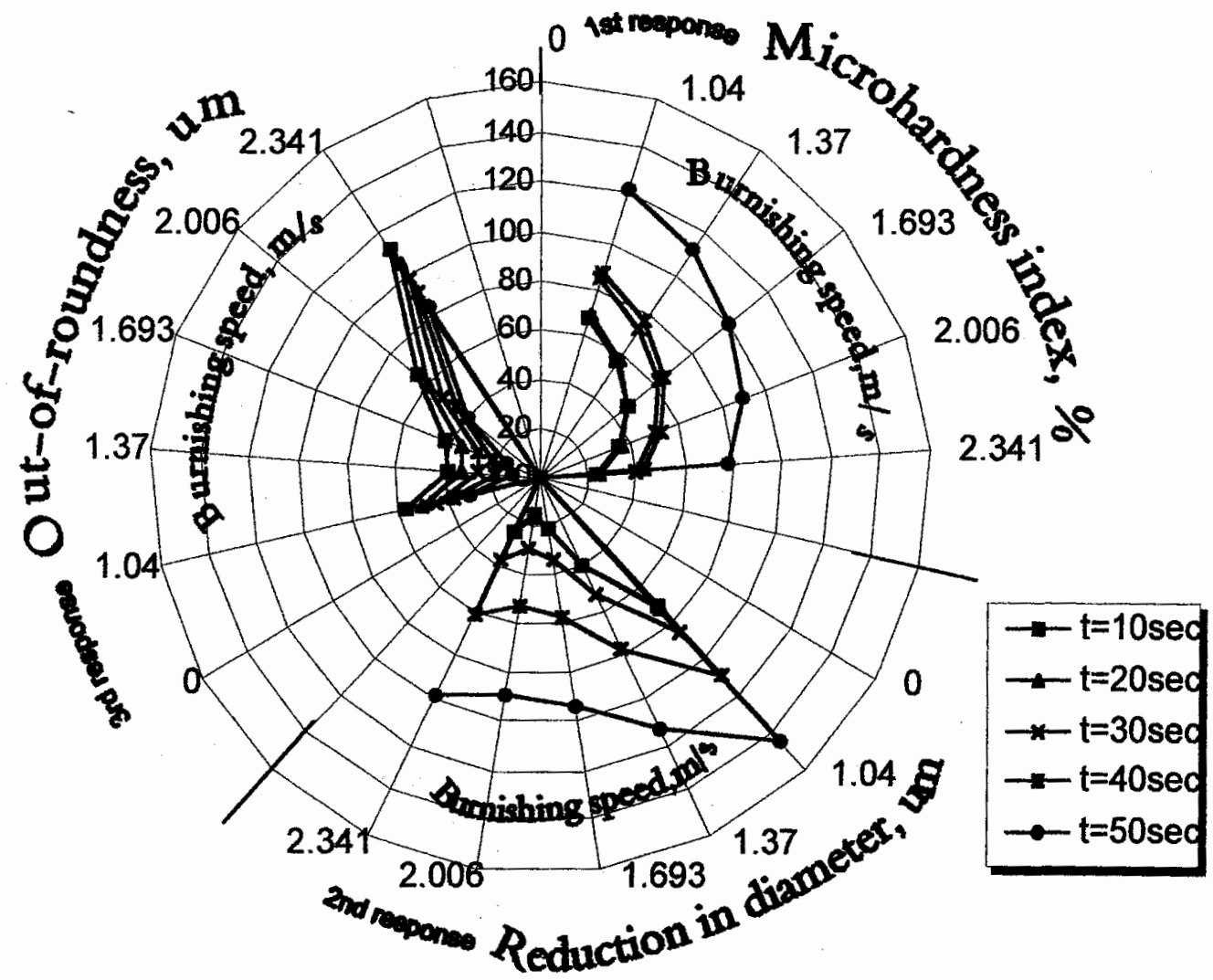

Figure 7: Effect of burnishing speed and burnishing time on microhardness index, reduction in diameter and out-of-roundness at $\mathrm{d}=0.8 \mathrm{~mm}$ and $\mathrm{H}=70 \mathrm{HB}$ 


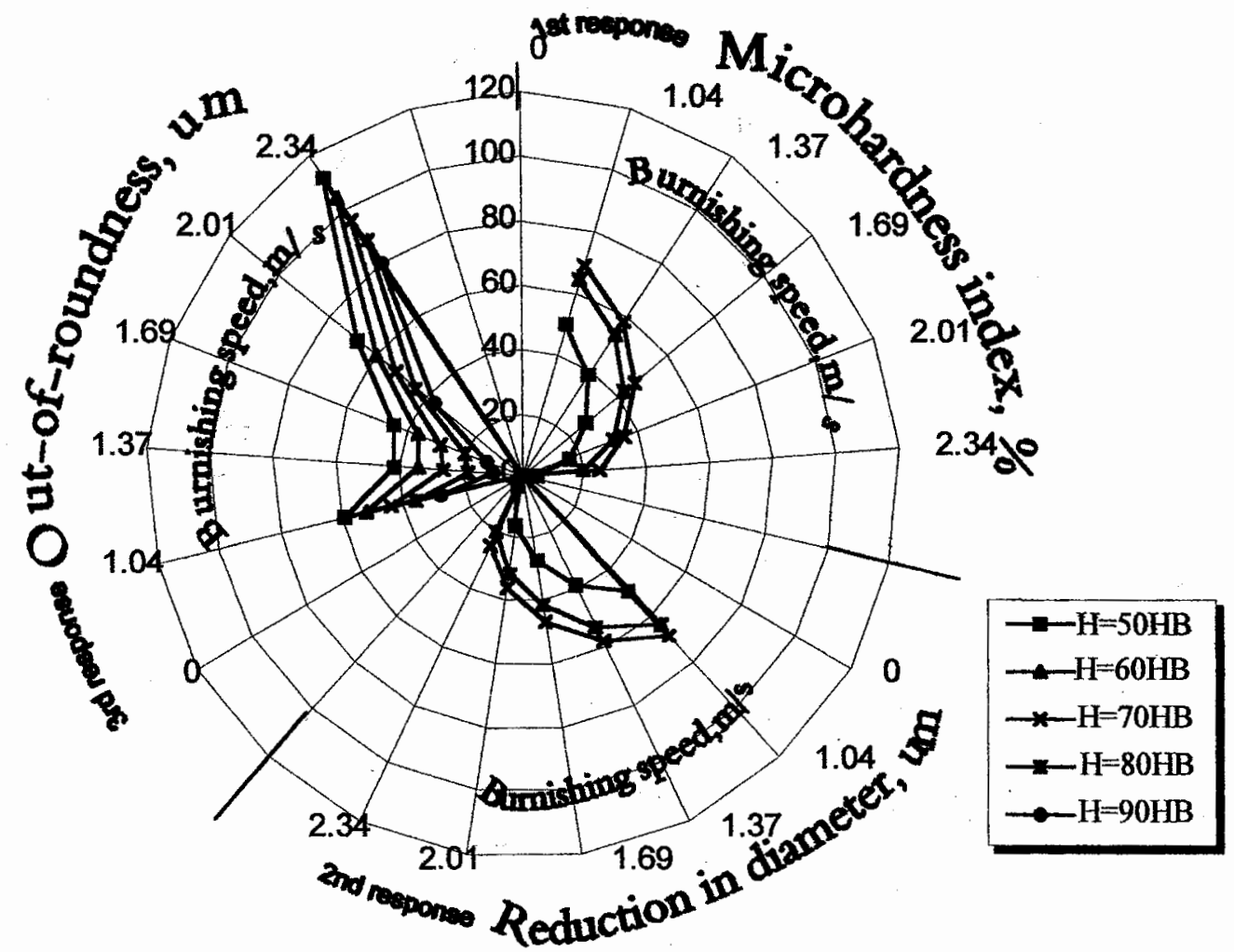

Figure 8: Effect of burnishing speed and initial hardness on the microhardness index, reduction in diameter and out-of-roundness at $\mathrm{d}=0.8 \mathrm{~mm}$ and $\mathrm{t}=30 \mathrm{sec}$

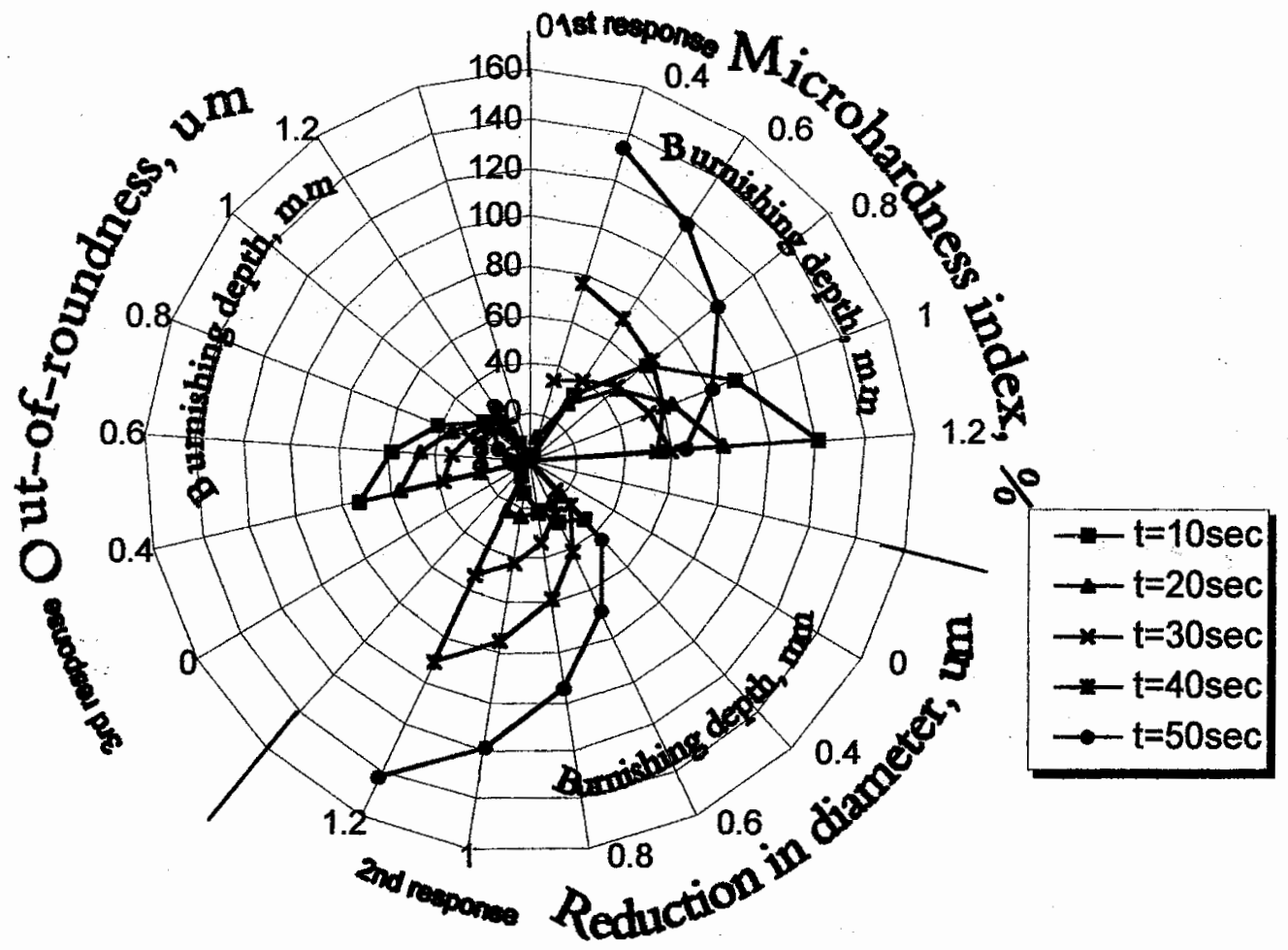

Figure 9: Effect of burnishing depth and burnishing time on the microhardness index, reduction in diameter and out-of-roundness at $v=1.69 \mathrm{~m} / \mathrm{s}$ and $\mathrm{H}=70 \mathrm{HB}$ 


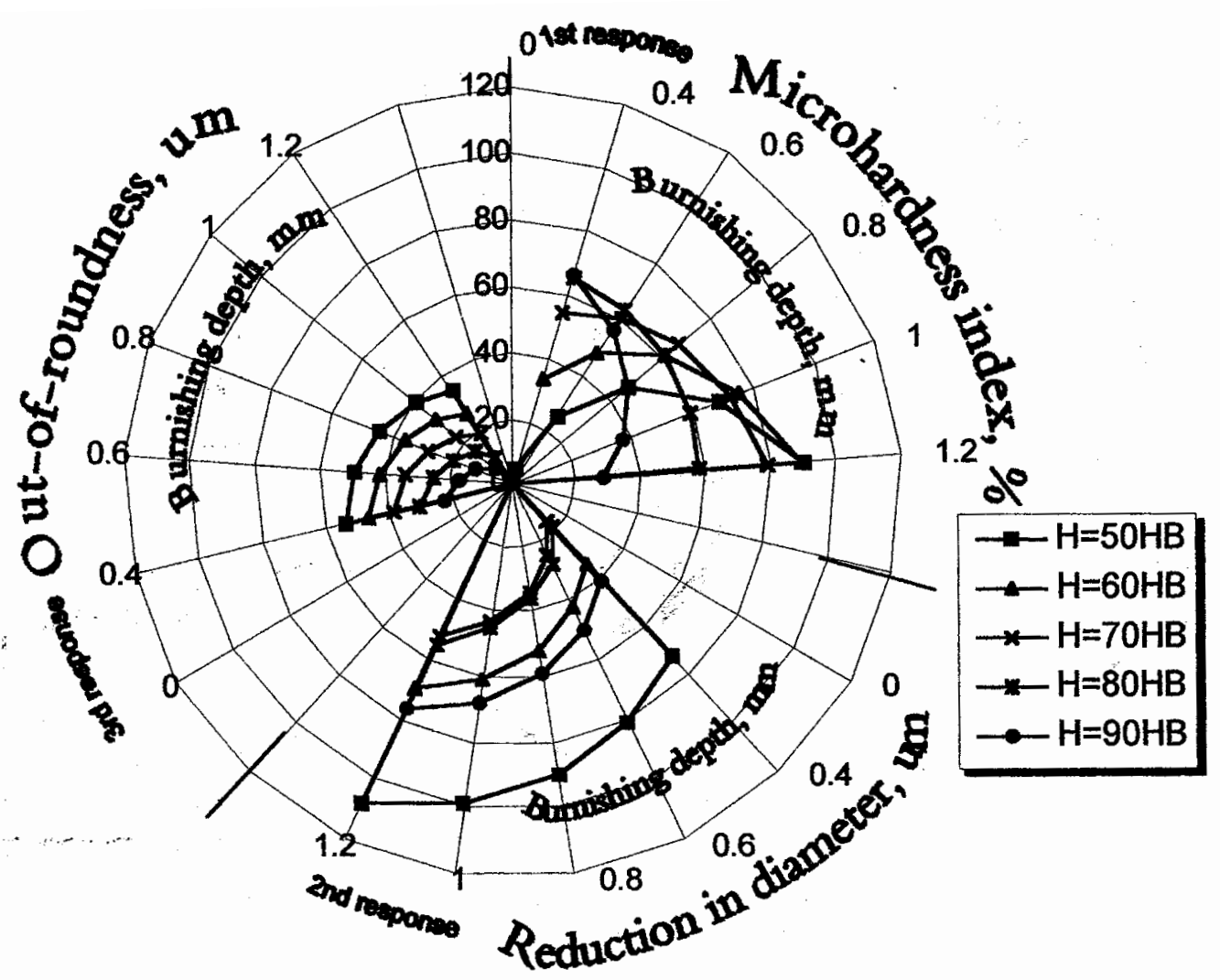

Figure 10: Effect of burnishing depth and initial hardness on the microhardness index, reduction in diameter and out-of-roundness at $v=1.69 \mathrm{~m} / \mathrm{s}$ and $\mathrm{t}=30 \mathrm{sec}$.

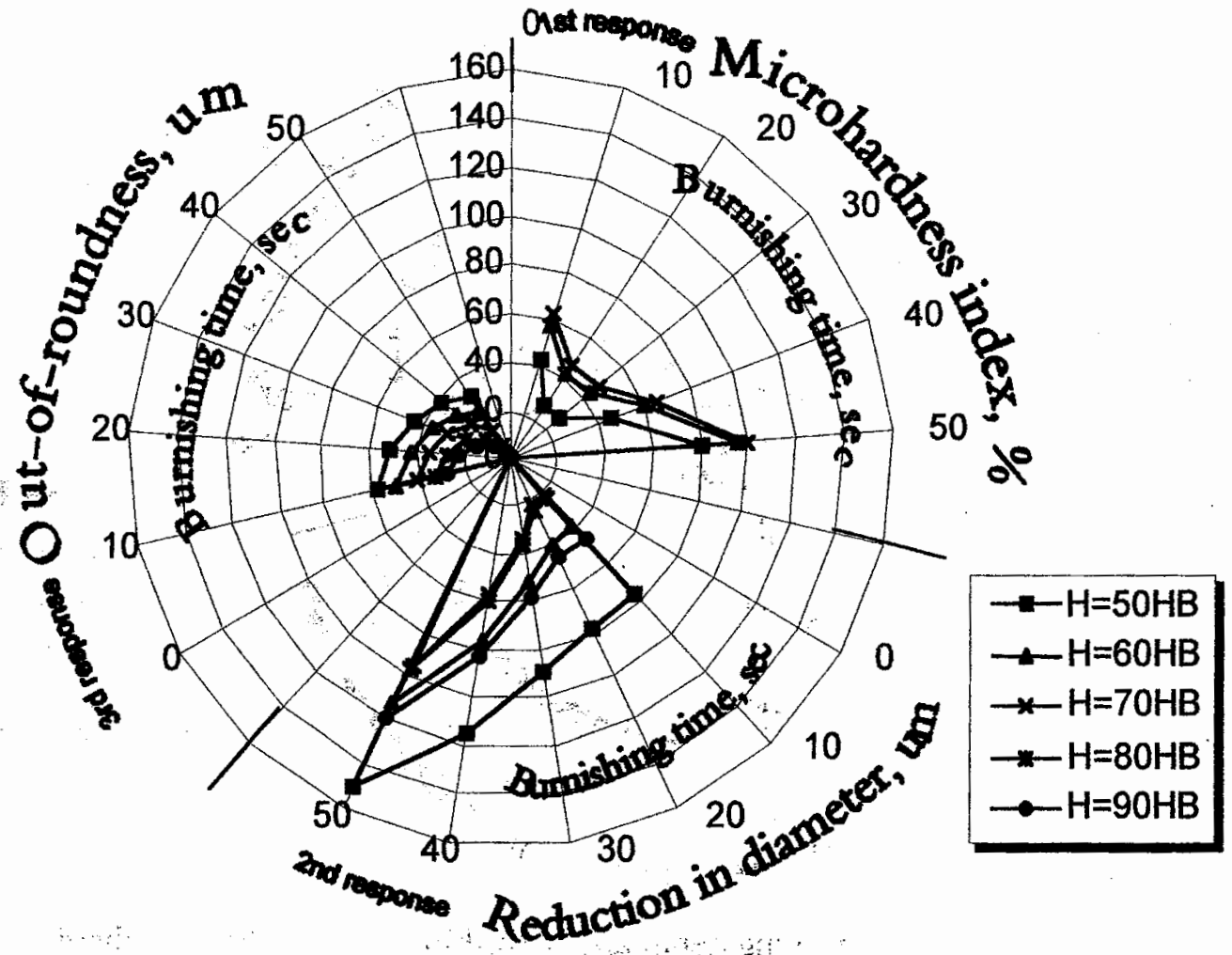

Figure 11: Effect of burnishing time and initial hardness on the microhardness index, reduction in diameter and out-of-roundness at $v=1.69 \mathrm{~m} / \mathrm{s}$ and $\mathrm{d}=0.8 \mathrm{~mm}$ 
تأثير متفيرات عملية الصقل (الذعك) العودى على خصائص

\section{السطح للمعادن المختلفة}

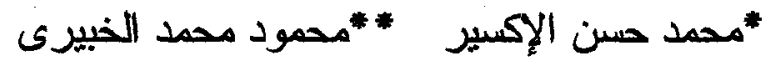

*مرس، **أستاذ مساعد - قسم هنسة الإنتاج و التصميم الميكانيكي

كلية الهنسة بشبين الكوم - مصــــــر

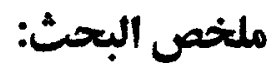

تلعـب عمليـة الصقـل (الدعـك) دورا هامـا فـى زيــادة درجــة تحســن الأسـطح المشغلة بالطرق التقليدية حيث تؤدى إلى زيادة مقاومة المعدن للاحتكاك وذلك نتيجة زيادة صلادة السطح المصقول. كذلك فإن عملية الصقـل تؤدى إلى زيـادة

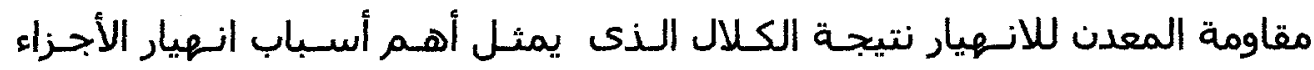
الميكانيكية.

لذلك يهدف البحث إلى دراسة متعمقة لتأثير ثلاثة من عوامـل الصقـل العمـودى وهى( سـرعة الصقل، عمق التغلغل، و زمن الصقل، بالإضافة إلى أخـذ الصلادة

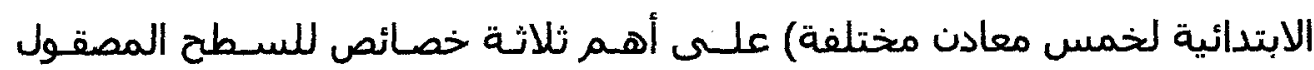
وهى (نسبة التغير فى صلاده السطح، الانحراف عـن الاسـتدارة و كذلـك التغـير فى قطر الشغلة المصقولة).

وقد أظهرت النتائج أن كل المتغيرات المستخدمة لها تـأثير على النواته بنسسب مختلفة. فقد وجد أن عمق التغلغل و زمن عملية الصقل أكثر تأثيرا و تحكما فـى

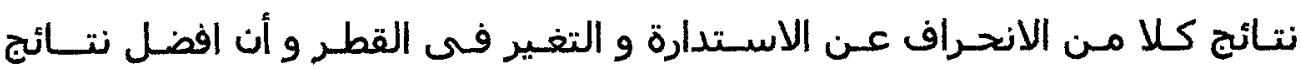

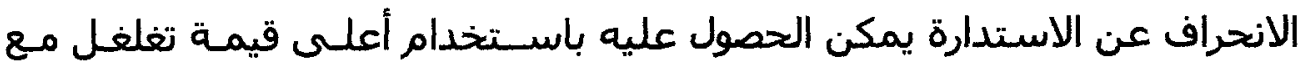

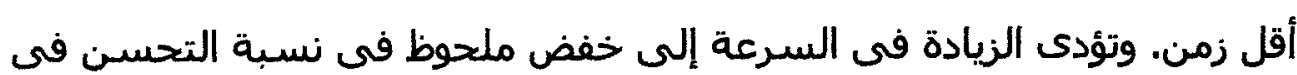

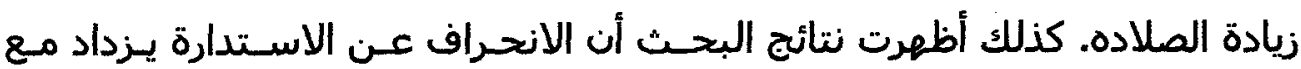
خفض الصلاده الابتدائية للمعادن المستخدمة فى هذا البحث . 